UDC 544.47:544.344

\title{
PRODUCTION OF NANOSTRUCTURED VANADIUM OXIDE THIN FILMS ON THE SURFACE OF METAL OXIDE CARRIERS BY THERMAL DECOMPOSITION OF VANADYLIC ORGANOMETALLIC COMPLEXES $\left(\mathrm{C}_{5} \mathrm{H}_{5}\right)_{2} \mathrm{~V}=\mathrm{O} \cdot(\mathrm{THF})_{5} \mathrm{WITH}$ CYCLOPENTADIENYL LIGANDS
}

\author{
G.Z.Suleymanov \\ M.Nagiyev Institute of Catalysis and Inorganic Chemistry, NAS of Azerbaijan \\ suleymanov.1948@mail.ru
}

Received 25.12.2017

\begin{abstract}
By thermal decomposition penta-kis of tetrahydrofuranate solvated vanadyl complex with $\left(\mathrm{C}_{5} \mathrm{H}_{5}\right)_{2} \mathrm{~V}=\mathrm{O} \cdot(\mathrm{THF})_{5}$ (1), produced by hydrolysis of bis-cyclopentadienyl of vanadium(III) chloride $\left(\mathrm{C}_{5} \mathrm{H}_{5}\right)_{2} \mathrm{VCl}$ (2) under weak basicity vanadium oxide nanostructured thin films on the surface of metal oxide carrier were produced. It was detected that vanadium oxide thin films with thickness of $45 \mathrm{~nm}$ were produced at concentration $0.1 \mathrm{~mol} / 100 \mathrm{ml}$ solvent (THF) with capacity of $50 \mathrm{ml}$ of spheric $\mathrm{Al}_{2} \mathrm{O}_{3}$ with $5-7 \mu \mathrm{m}$ carrier.
\end{abstract}

Keywords: vanadium oxide, catalyst system, catalyst surface, oxidative dehydrogenation, isobutane, isobutylene.

\section{Relevance of the problem}

The requirement of chemical industry for $\mathrm{C}_{2}-\mathrm{C}_{4}$-olefins continuously grows, and the existing capacities can be insufficient [1].

At the same time among $\mathrm{C}_{2}-\mathrm{C}_{4}$-olefins the most flexible is $\mathrm{C}_{4}$ - isobutylene [2], which at present is used as a monomer for producing polyisobutylene, butyl rubber and raw materials for the production of methyl acrylate and other important chemical products [3].

Presently in industry isobutylene is produced by dehydrogenation of isobutane over chromia-alumina catalyst [4]. At the beginning of 2005 total production of isobutylene by this technology [5] made up more than 3 million tonnes. It should be noted that oxidizing dehydrogenation of isobutane attracts practitioners as a potential alternative way of producing isobutylene. Unlike traditional dehydration of isobutene in the presence of an oxidizer equilibrium shifts towards isobutylene and it is an exothermic process.

\section{Experimental part}

All reactions and the yield of by-products were performed in nitrogen atmosphere.

Preparation conditions of organometallic compound of vanadium(III). For this purpose in nitrogen atmosphere $0.5 \mathrm{~mol}$ or 15.7 of anhydrous $\mathrm{VCl}_{3}$ in $50 \mathrm{ml}$ of dehydrated tetrahydrofuran (THF) is dissolved, then it is cooled till $10^{\circ} \mathrm{C}$ and $\mathrm{NH}_{2} \mathrm{Na}$ in $50 \mathrm{ml}$ of $n$-heptane which was pro- duced in a separate reaction between $13.2 \mathrm{~g}$ of monocyclopentadiene $\left(\mathrm{C}_{5} \mathrm{H}_{6}\right)$ and of $4.6 \mathrm{~g}$ sodium amide, was added by portion. Deposited sodium cyclopentadionate $\mathrm{C}_{5} \mathrm{H}_{5} \mathrm{Na}$ after decantation of heptane the whole $\mathrm{C}_{5} \mathrm{H}_{5} \mathrm{Na}$ was added into reaction mixture. After 2-hour stirring, it was stopped. Turbid solution was settled. The deposit is separated. Solution was evaporated to minimum in a volume and cooled till $-10^{\circ} \mathrm{C}$. In a few minutes pale blue polycrystals deposit. According to the data of elemental analysis fresh weight of a target product was $74 \%$ of its output. The compound corresponds to chemical formula $\mathrm{C}_{10} \mathrm{H}_{10} \mathrm{VCl} \cdot 5\left(\mathrm{C}_{4} \mathrm{H}_{8} \mathrm{O}\right)$ in which all molecules of THF are coordinated coordination bonds of vanadium(III) and THF cations. Temperatures of the beginning of decomposition $T_{\text {b.d. }}=140^{\circ} \mathrm{C}$, end of decomposition $T_{\text {f.d. }}=160^{\circ} \mathrm{C}$. According to thermogravimetric data decomposition of compounds occurs to $130^{\circ} \mathrm{C}$.

Formation of $\mathrm{V}_{2} \mathrm{O}_{3}$ and $\mathrm{V}_{2} \mathrm{O}_{5}$ nanostructured catalytic systems over metal oxide carrier and conversion of isobutane to isobutylene by oxidizing dehydrogenation with them.

Decomposition temperature on $\gamma-\mathrm{Al}_{2} \mathrm{O}_{3}$ carrier is $110-120^{\circ} \mathrm{C}$, bis-cyclopentadienyl vanadyl penta-kis-tetrahydrofuranate

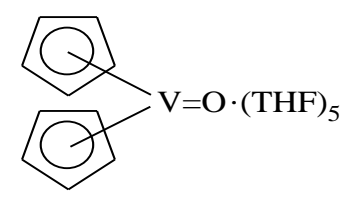


is absorbed from $25 \mathrm{~g}$ of spheric $\mathrm{Al}_{2} \mathrm{O}_{3}$ which varies at the range of sizes prepared for $5-7 \mathrm{~mm}$ solution in $0.1 \mathrm{~mol} / 100 \mathrm{ml}$ tetrahydrofuranate THF of I complex, then it is mixed with magnetic mixer at medium rate until only traces of the compound remain in the solution.

In the next stage the solvent is decanted and separated from $\mathrm{Al}_{2} \mathrm{O}_{3}$, the residual solvent is fully removed from the surface of $\mathrm{Al}_{2} \mathrm{O}_{3}$ in $60-70^{\circ} \mathrm{C}$ temperature range. In the next stage the sample is thermally processed. Then the sample is deposited on metal oxide by thermal decomposition of $\left(\mathrm{C}_{5} \mathrm{H}_{5}\right)_{2} \mathrm{~V}=\mathrm{O} \cdot(\mathrm{THF})_{5}$ vanadyl complex. For this $0.01 \mathrm{~mol}$ or $0.04271 \mathrm{~g}$ of vanadyl complex is dissolved by the way of intensive mechanical mixing in nitrogen in 100 $\mathrm{ml}$ of hydrated tetrahydrofuran solvent. Then 7-9 mm of spheric $\mathrm{Al}_{2} \mathrm{O}_{3}$ is added at room temperature and left for absorption. Absorption process is performed till the compound in solution is fully absorbed. In the next stage solvent (THF) is heated at the temperature range of 30 $40^{\circ} \mathrm{C}$ and is fully removed in nitrogen medium and processed at $400-500^{\circ} \mathrm{C}$.

\section{Results}

As a result of investigation of the wide literature it was found out that in the production of thin films and metal coatings on the basis of both organic $\left(\mathrm{R}^{\prime}\right)$ and carbonyl (CO) ligand compounds of transition elements [6] are widely used. First of all it is conditioned with the fact that thermal decomposition of compounds with $\mathrm{M}-\mathrm{R}, \mathrm{M}-\mathrm{C} \equiv \mathrm{O}(\sigma$ and $\pi)$ bond at the temperature range of $100-200^{\circ} \mathrm{C}$ and are converted to thermally decomposed products by forming dimer organic products without any residual compounds. Metal or metal oxides separated from organic residue form metal or metal oxide layer on carrier and then can act as a more effective catalyst like systems with active center [6]. search work

Considering the abovementioned the re-

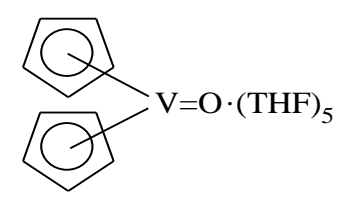

describes the creation of nanostructured catalytic systems on $\mathrm{Al}_{2} \mathrm{O}_{3}$ using organometallic compound, the research of using them as a catalyst in the conversion of isobutane into isobutylene. For this purpose $100 \mathrm{~cm}^{3}$ of 7-9 mm spheric $\mathrm{Al}_{2} \mathrm{O}_{3}$ is added into $250 \mathrm{ml}$ of three-neck flask and a solution containing $0.0427 \mathrm{~g}$ (I) complex and dissolved in $100 \mathrm{ml}$ THF is added into it and mixed ( 1.5 hour) until only traces of (I) complex remain in a solution. Then catalyst is separated from solution by decantation way in nitrogen medium and is given to furnace for thermal processing. In furnace it is mixed intensively and then is left for thermal processing for 1 hour at average temperature $140-150^{\circ} \mathrm{C}$. The sample is brought till room temperature and is again left for thermal processing to be fixed on the layer. For this purpose the sample is annealed in nitrogen at $180-190^{\circ} \mathrm{C}$.

The catalytic system was used in the conversion of isobutane to isobutylene. Figure 1 shows the SEM view of $\mathrm{V}_{2} \mathrm{O}_{3}-$ vanadium(III) oxide thin film deposited on $\mathrm{Al}_{2} \mathrm{O}_{3}$ carrier and its elemental composition was defined.

In SEM the thickness of $\mathrm{V}_{2} \mathrm{O}_{3}$ coating on $\mathrm{Al}_{2} \mathrm{O}_{3}$ carrier is given. Figure 1 shows the characteric X-ray spectrum. It was confirmed that the studied dust particles consist of various size particles of aluminium oxide and vanadium oxide.

According to the results of researches it was found that $45 \mathrm{~nm} \mathrm{~V} \mathrm{O}_{3}$ coating and 100 $\mathrm{cm}^{3} 7-9 \mathrm{~mm}$ spheric $\mathrm{Al}_{2} \mathrm{O}_{3}$ which was dissolved in $0.0427 \mathrm{~g} / 100 \mathrm{ml} \mathrm{THF}$ solvent on the basis of $\left(\mathrm{C}_{5} \mathrm{H}_{5}\right)_{2} \mathrm{~V}=\mathrm{O} \cdot(\mathrm{THF})_{5}$ vanadyl organometallic compound, were determined.

As to the formation of a structure between $\mathrm{V}_{2} \mathrm{O}_{3}$ on $\mathrm{Al}_{2} \mathrm{O}_{3}$ surface it should be first noted that when (I) complex is thermally decomposed the formation of coatings by chemical impact of $[\mathrm{V}=\mathrm{O}]$ anion radical on $\mathrm{Al}_{2} \mathrm{O}_{3}$ carrier was studied. Researches show that $[\mathrm{V}=\mathrm{O}]$ fragment with high energy forms<smiles>COI1CCCO1</smiles>

manganese oxide coating by migrating to $\mathrm{Al}-\mathrm{O}$ bond on $\mathrm{Al}_{2} \mathrm{O}_{3}$.

As a result it enables to form more active nanostructured catalytic system. In the work oxidative and dehydrogenation properties of $\mathrm{C}_{2}-\mathrm{C}_{4}$ hydrocarbons of thin film nanostructured vanadium oxide were studied. It was shown on 
the example of $\mathrm{C}_{4}$ - isobutane that isobutane molecule $\mathrm{V}_{2} \mathrm{O}_{5}$ thin film on $\mathrm{Al}_{2} \mathrm{O}_{3}$ carrier conforms to the morphology of isobutane in the range of $400-500^{\circ} \mathrm{C}$ and allows performing the process more efficiently by dehydrogenating more selectively according to the scheme:

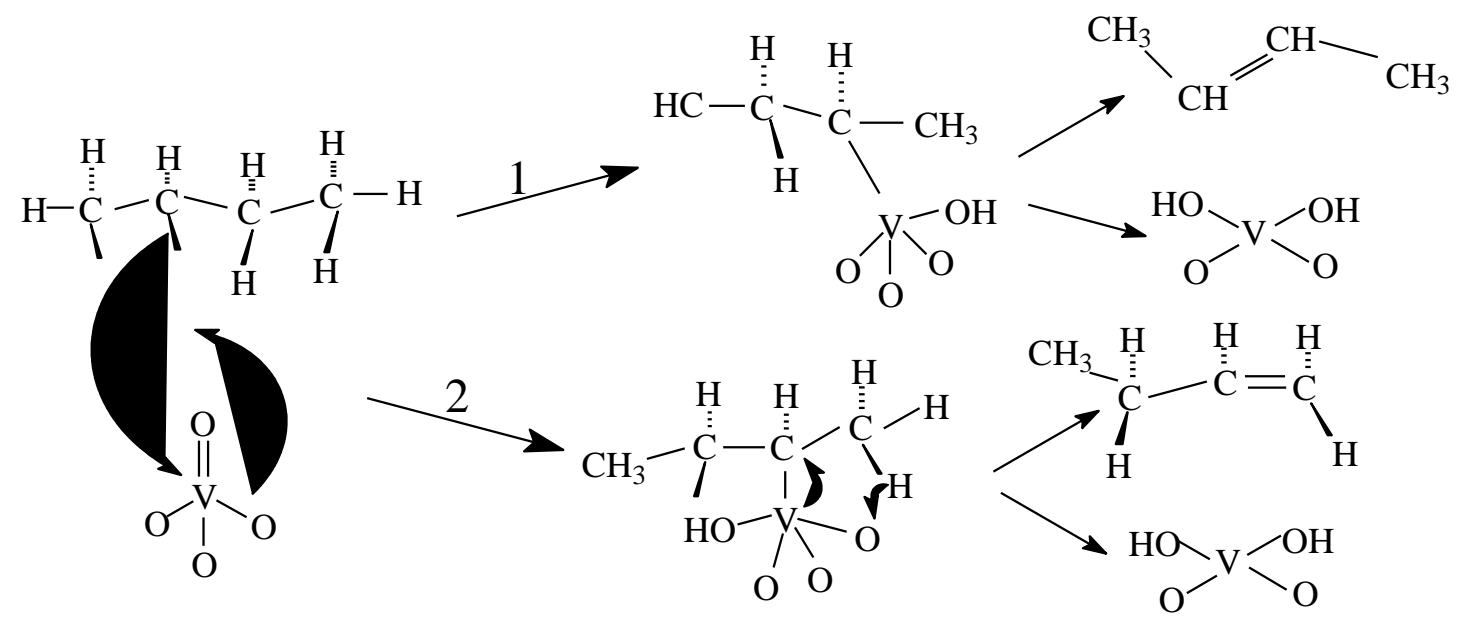

Probable mechanism of conversion process of isobutane to isobutylene.

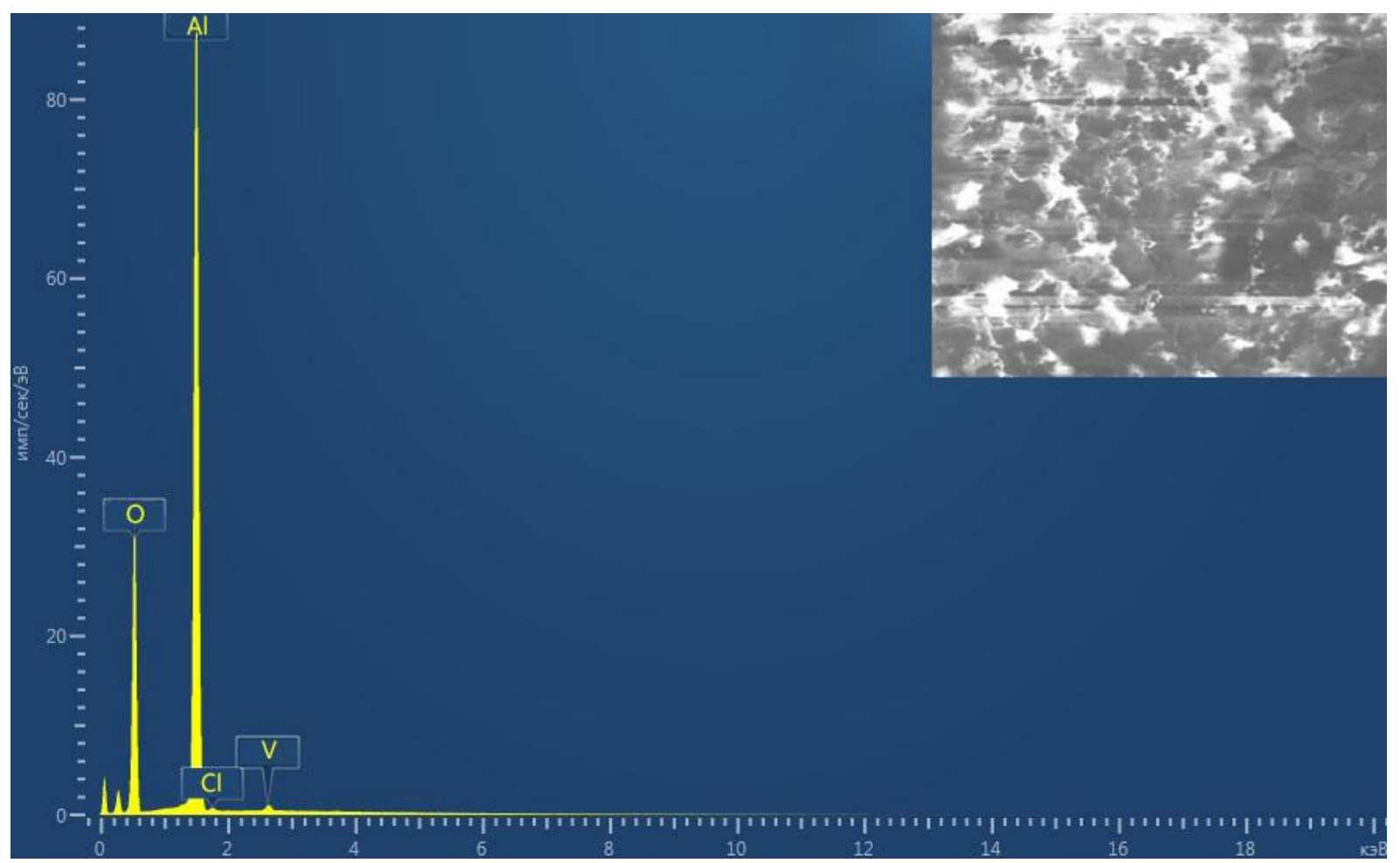

Fig. 1. Elemental analysis and composition of SEM-substance. 


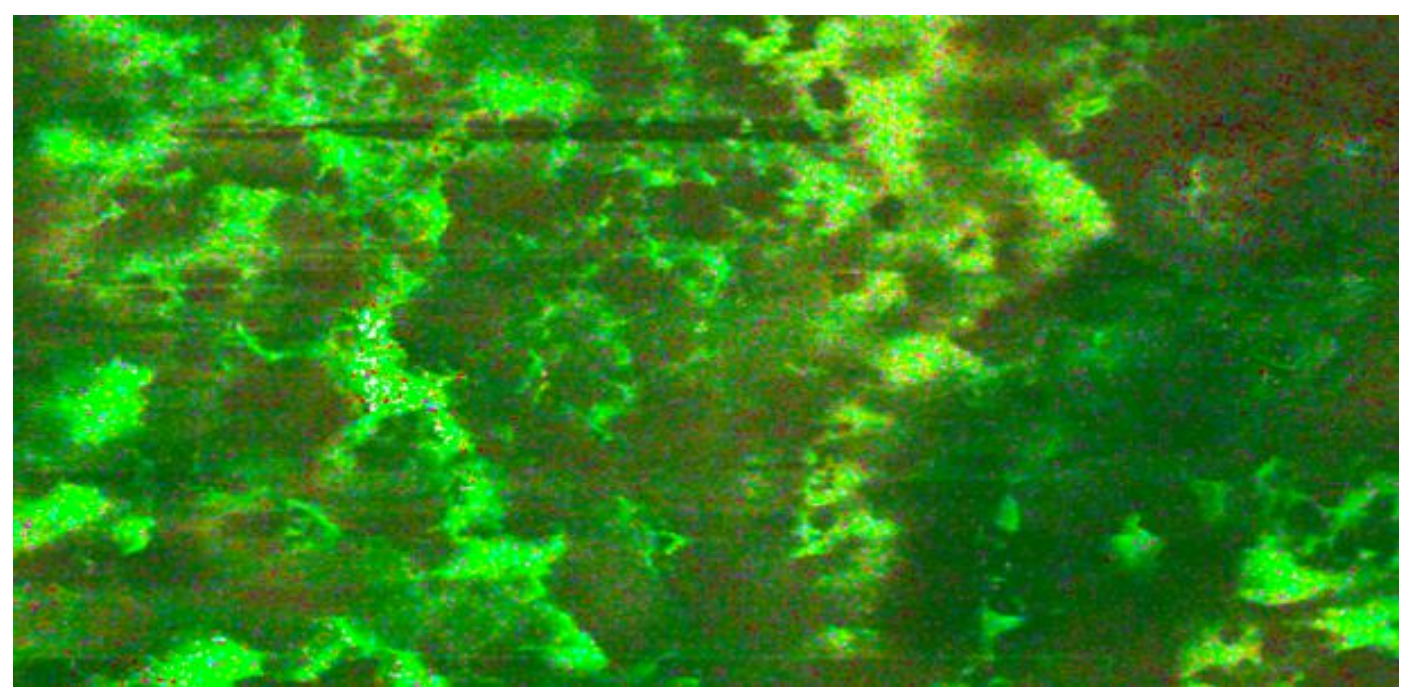

Fig.2. Visual and SEM spectral image of $\left(\mathrm{C}_{5} \mathrm{H}_{5}\right)_{2} \mathrm{~V}=\mathrm{O} \cdot 5(\mathrm{THF})$ complex deposited on $\mathrm{Al}_{2} \mathrm{O}_{3}$ after thermal processing.

Thus, experimental results on the oxidative dehydrogenation of isobutane in the presence of vanadium-containing oxide and nanostructured catalysts are presented. The features of the structures of the catalytic systems on the efficiency of their action on the activity and selectivity of the dehydrogenation process are studied. Oxidative dehydrogenation of isobutane, an industrial promising process for the preparation of isobutylene, was studied in the presence of vanadium oxide catalysts deposited on the surface of $\gamma-\mathrm{Al}_{2} \mathrm{O}_{3}$ by decomposition with organometallic complex compounds of vanadium(III) and (V). The catalytic effect in the target and side reactions is compared with the results of studying the characteristics of their volume and surface by X-ray diffraction, X-ray photoelectron spectroscopy, temperature-programmed hydrogen reduction, and a number of others. Physicochemical method of investigation established that depending on the initial vanadium metal complex taken, either the amount of reactive mobile oxygen increases or decreases, thereby promoting more efficient course of the oxide-reduction cycle and more stable operation of the catalyst.

\section{References}

1. Spiridonova D.V., Fokina E.A., Krylov O.V. Adsorbtciia benzola i khlorbenzola na $\gamma-\mathrm{Al}_{2} \mathrm{O}_{3}$, $\mathrm{V}_{2} \mathrm{O}_{5} / \gamma-\mathrm{Al}_{2} \mathrm{O}_{3}$ i $\mathrm{CuCl} / \gamma-\mathrm{Al}_{2} \mathrm{O}_{3} / /$ Kinetika i kataliz. 2002. T.118. № 6. S.1495-1500.

2. Blasco T. Galili I., Lopoz-Nielo J.M., Trifiro F. Oxidative dehydrogenation of ethane and butane on $\mathrm{VO}_{x} / \mathrm{Al}_{2} \mathrm{O}_{3}$ catalysts // J. Catal. 1997. V.169. No 1. P. 203-211.

3. Santacexaria E., Cozzolino M., Veneria I.M., Tesser R. Vanadium based catalysts prepared by grafting: preparation, properties and performances in the ODH of butane // App. Catal. A. 2004. V. 270. No 1-2. P. 177-192.

4. Sardarly A.M., Suleymanov G.Z., Kahramanova Sh.I., Taghiyev D.B. Study of the process of oxidative dehydrogenation of isobutene on vanadium(III) containing oxide and nanostructured vanadium(V) containing catalytic systems // Eur. Sci. 2017. No 8 (30). P. 6-10.

5. D.-Y. Hong, J.-S. Chang, V.P. Vislovskiy, S.-E. Park, Y.-H. Park, J.S. Yoo. Dehydrogenation of ethylbenzene with carbon dioxide over $\mathrm{Mg}$ modified alumina-supported $\mathrm{V}$-Sb oxide catalysts // Chemistry Letters (Chemical Society of Japan). 2006. V. 35. No 1. P. $28-29$.

6. D.-Y. Hong, V.P. Vislovskiy, Y.K. Hwang, J.-S. Chang. Oxidative dehydrogenation of ethylbenzene with carbon dioxide over layered double hydroxide-derived vanadium catalysts // The $11^{\text {th }}$ Korea-Japan Symposium on Catalysis (Seoul, Korea, 2007) // Book of Abstracts. P. 34. 
VANADIL METALÜZVI KOMPLEKSINIIN $\left(\mathrm{C}_{5} \mathrm{H}_{5}\right)_{2} \mathrm{~V}=\mathrm{O} \cdot(\mathrm{THF})_{5}$ TSIKLOPENTADİENIL LİQANDLARI İLO TERMIKI PARÇALANMASINDAN ISTIFADə ETMOKLə METALOKSID DAŞIYICI SəTHINDə NANOSTRUKTURLAŞDIRILMIŞ VANADİUM OKSID ÖRTÜYÜNÜN ALINMASI

\section{G.Z.Süleymanov}

bis-Tsiklopentadienil vanadium(III) xloridin $\left(\mathrm{C}_{5} \mathrm{H}_{5}\right)_{2} \mathrm{VCl}$ (2) zəif qələvi mühitində hidrolizindən alınmış solvatlaşdırılmış penta-kis-tetrahidrofuranat vanadium kompleksinin $\left(\mathrm{C}_{5} \mathrm{H}_{5}\right)_{2} \mathrm{~V}=\mathrm{O}(\mathrm{THF})_{5}$ termiki parcalanması ilə metaloksid daşıyıcı səthində nanostrukturlaşmış vanadiumoksid nazik örtük alınmışdır. Məlum olmuşdur ki, 5-7 mk ölcüdə hissəcikli sferik $\mathrm{Al}_{2} \mathrm{O}_{3}$ üzərinə çökdürülmüş $50 \mathrm{ml}$ həcmli həlledicinin (THF) $0.1 \mathrm{~mol} / 100 \mathrm{ml}$ qatıllğında $45 \mathrm{~nm}$ qalınlığında nazik vanadiumoksid təbəqəsi alınır

Açar sözlar: vanadium oksid, katalitik sistem, katalizatorun səthi, oksidlaşdirici dehidrogenlaşmə, izobutan, izobutilen.

\section{ПОЛУЧЕНИЕ НАНОСТРУКТУРИРОВАННЫХ ВАНАДИЙОКСИДНЫХ ТОНКИХ ПЛЁНОК НА ПОВЕРХНОСТИ МЕТАЛЛООКСИДНЫХ НОСИТЕЛЕЙ ПУТЁМ ТЕРМИЧЕСКОГО РАЗЛОЖЕНИЯ ВАНАДИЛЬНОГО МЕТАЛЛООРГАНИЧЕСКОГО КОМПЛЕКСА $\left(\mathrm{C}_{5} \mathrm{H}_{5}\right)_{2} \mathrm{~V}=\mathrm{O} \cdot(\mathrm{TГ} Ф)_{5}$ С ЦИКЛОПЕНТАДИЕНИЛЬНЫМИ ЛИГАНДАМИ}

\section{Г.3.Сулейманов}

Путём термического разложения пента-кис-тетрагидрофуранатного сольватированного ванадильного комплекca $\left(\mathrm{C}_{5} \mathrm{H}_{5}\right)_{2} \mathrm{~V}=\mathrm{O} \cdot(\text { ТГФ })_{5}$, полученного гидролизом бис-циклопентадиенилванадий(III)хлорида $\left(\mathrm{C}_{5} \mathrm{H}_{5}\right)_{2} \mathrm{VCl}(2)$ в условиях слабой основности получены ванадийоксидные наноструктурированные тонкие плёнки на поверхности металлооксидного носителя. Обнаружено, что при концентрации комплекса 0.1 моль/100 мл растворителя (ТГФ) объёмом 50 мл, нанесенного на сферический $\mathrm{Al}_{2} \mathrm{O}_{3}$ с размером частиц 5-7 мк, получена ванадийоксидная тонкая плёнка толщиной 45 нм.

Ключевые слова: оксид ванадия, каталитическая система, поверхность катализатора, окислительное дегидрирование, изобутан, изобутилен. 